\title{
Mineral Sources of Calcium and Phosphorus in Soils of the Northeastern United States
}

\author{
Carmen A. Nezat* \\ Dep. of Geological Sciences \\ Univ. of Michigan \\ 1100 North University Ave. \\ Ann Arbor, MI 48109 \\ Current address: \\ Dep. of Geology \\ Eastern Washington Univ. \\ 130 Science Building \\ Cheney, WA 99004
}

\section{Joel D. Blum \\ Dep. of Geological Sciences \\ Univ. of Michigan \\ 1100 North University Ave. \\ Ann Arbor, MI 48109}

\section{Ruth D. Yanai \\ Dep. of Forest and Natural Resour. Management \\ 320 Bray Hall \\ SUNY-ESF \\ One Forestry Dr. \\ Syracuse, NY 13210}

\section{Byung Bae Park \\ Dep. of Forest and Natural Resour. Management \\ 320 Bray Hall \\ SUNY-ESF \\ One Forestry Dr. \\ Syracuse, NY 13210 \\ Division of Forest Ecology \\ Korea Forest Research Inst. \\ Seoul 130-712 \\ South Korea}

Apatite is ubiquitous in igneous, metamorphic, and sedimentary rocks, although usually in trace amounts. Apatite is the primary source of $\mathrm{P}$ and, due to its relatively rapid dissolution rate, can be an important $\mathrm{Ca}$ source in noncarbonate soils. We investigated the distribution of apatite using a $1 \mathrm{~mol} \mathrm{~L}^{-1} \mathrm{HNO}_{3}$ extraction of glacial till soils at 31 sites across the northeastern United States. Parent materials formed from crystalline silicate and clastic sedimentary rocks contained 0.2 to $41 \mathrm{mmol} \mathrm{Ca} \mathrm{kg}{ }^{-1}$ soil and 1 to $27 \mathrm{mmol} \mathrm{P} \mathrm{kg}^{-1}$ soil; at most of these sites, the $\mathrm{P} / \mathrm{Ca}$ ratio was approximately $3: 5$, indicating the dominance of apatite. Parent materials underlain by carbonate rocks had 3 to $16 \mathrm{mmol} \mathrm{P} \mathrm{kg}^{-1}$ soil, similar to the noncarbonate groups, but had large concentrations of easily weathered Ca (56-1890 mmol kg-1 soil) due to the extraction of carbonates. The same extraction procedure applied to samples from the upper $30 \mathrm{~cm}$ of mineral soil at the same sites showed lower concentrations of both $\mathrm{Ca}$ and $\mathrm{P}$ than in the $\mathrm{C}$ horizon, except for a few sites where the upper soil layers probably developed in different parent materials than the current $\mathrm{C}$ horizon. We also measured neutral-salt-exchangeable Ca concentrations in the 10 - to $20-\mathrm{cm}$ depth increment. Exchangeable Ca concentrations in soils underlain by carbonate bedrock were an order of magnitude higher than in soils underlain by crystalline silicate and clastic sedimentary rocks. For this reason, the exchangeable $\mathrm{Ca}$ concentration in the upper soil was correlated to the concentration of $1 \mathrm{~mol} \mathrm{~L}^{-1} \mathrm{HNO}_{3}$ extractable $\mathrm{Ca}$ in the underlying soil parent material. To predict concentrations of apatite in parent materials and the concentrations of exchangeable $\mathrm{Ca}$ in overlying horizons in greater detail would require more specific characterization of bedrock sources.
$\mathrm{U}$ nderstanding mineral sources of $\mathrm{Ca}$ in soils of the northeastern United States is important because plant-available Ca has been leached from the soil at accelerated rates for several decades (Lawrence et al., 1999; Likens et al., 1998), possibly resulting in $\mathrm{Ca}$ limitation in some forest ecosystems (Horsley et al., 2000; Huntington, 2005; Long et al., 1997). Plagioclase,

Soil Sci. Soc. Am. J. 72:1786-1794

doi:10.2136/sssaj2007.0344

Received 19 Sept. 2007.

Corresponding author (cnezat@ewu.edu).

(C) Soil Science Society of America

677 S. Segoe Rd. Madison WI 53711 USA

All rights reserved. No part of this periodical may be reproduced or transmitted in any form or by any means, electronic or mechanical, including photocopying, recording, or any information storage and retrieval system, without permission in writing from the publisher. Permission for printing and for reprinting the material contained herein has been obtained by the publisher. the dominant Ca-bearing mineral in noncarbonate soils in the region, weathers too slowly to compensate for the Ca lost from the exchangeable pool (Likens et al., 1998; Nezat et al., 2004). Apatite, $\mathrm{Ca}_{5}\left(\mathrm{PO}_{4}\right)_{3}(\mathrm{~F}, \mathrm{Cl}, \mathrm{OH})$, although it is usually present only in trace amounts, may be an important mineral source of $\mathrm{Ca}$ because it dissolves several orders of magnitude more rapidly than plagioclase (Oxburgh et al., 1994; Valsami-Jones et al., 1998; Welch and Ullman, 1993). For example, at the Hubbard Brook Experimental Forest in New Hampshire, apatite represents $<1 \%$ of the soil mineral mass ( $12 \%$ of total $\mathrm{Ca}$ ) yet its dissolution is responsible for at least $20 \%$ of the Ca weathered from the soils since the area was deglaciated 14,000 yr ago (Nezat et al., 2004). In the Adirondack Mountains, apatite accounts for $\sim 1$ to $8 \%$ of the total Ca in some soil parent materials (Yanai et al., 2005).

Apatite is common in igneous, metamorphic, and sedimentary rocks. In igneous rocks, apatite is found in both plutonic and volcanic rocks ranging in chemical composition from 
felsic to ultramafic (Piccoli and Candela, 2002). In metamorphic rocks, apatite is found in pelitic, carbonate, basaltic, and ultramafic rocks of all metamorphic grades (Spear and Pyle, 2002). Apatite may appear as individual grains or as inclusions in aluminosilicate minerals such as feldspar and biotite. Apatite is also present in a variety of sedimentary rock types. In clastic rocks, both detrital and authigenic apatite have been found in rocks formed from continental and marine deposits (Bouch et al., 2002; Rasmussen, 1996; Roden-Tice and Tice, 2005). Apatite is also common in carbonate rocks, usually as carbonate-apatite, $\mathrm{Ca}_{5}\left(\mathrm{PO}_{4}, \mathrm{CO}_{3} \mathrm{OH}\right)_{3}(\mathrm{~F}, \mathrm{Cl}, \mathrm{OH})$ (Knudsen and Gunter, 2002). Sedimentary rocks may also contain biological apatite such as bones and teeth (Kohn and Cerling, 2002).

Because apatite is easily weathered, the concentrations of apatite in soils are expected to be lower than in the underlying parent material. The depletion of apatite from soil during soil development has been documented in chronosequence studies (Crews et al., 1995; Schlesinger et al., 1998; Walker and Syers, 1976). This depletion of apatite from surface soils accompanied by its persistence at depth has also been documented in relatively young soils (Beck and Elsenbeer, 1999; Blum et al., 2002). In addition, depletion of apatite from surface soils during the initial stages of weathering has been interpreted from the presence of apatite in young detrital lake sediments ( $<5000$ years old) following deglaciation and its absence in older lake sediments (Filippelli and Souch, 1999). Similarly, carbonate minerals weather very rapidly from soil profiles and are almost always depleted from surface horizons even in extremely young and poorly developed soils (Lichter, 1998; Vandenbygaart and Protz, 1995).

Although apatite is the most important primary mineral source of $\mathrm{P}$ and potentially an important source of $\mathrm{Ca}$, it is not routinely measured in operationally defined plant-available pools. Exchangeable $\mathrm{Ca}$ extracted by a neutral salt solution (Hendershot et al., 1993; Robertson et al., 1999) is the most common index of $\mathrm{Ca}$ availability. Plant-available $\mathrm{P}$ is commonly quantified using anion-exchange resins or a $0.5 \mathrm{~mol} \mathrm{~L}^{-1}$ $\mathrm{NaHCO}_{3}$ extraction (Hedley et al., 1982; Schlesinger et al., 1998). Neither of these methods assesses the amount of apatite susceptible to chemical weathering.

A new sequential extraction procedure allows apatite to be distinguished from more weathering-resistant aluminosilicate minerals in soils (Nezat et al., 2007). In recent studies, this procedure revealed that apatite was present in trace amounts in the lower B horizon and C horizon at the Hubbard Brook Experimental Forest in New Hampshire (Blum et al., 2002; Nezat et al., 2004) and at other sites in the northeastern United States underlain by granitoid bedrock (Yanai et al., 2005). The distribution of apatite in other soil parent materials across the northeastern United States is not well known.

The first objective of this study was to determine the concentration of $\mathrm{Ca}$ and $\mathrm{P}$ in easily weathered minerals in soil parent material at 31 sites with various bedrock lithologies across the northeastern United States. Based on our previously published sequential extraction method (Nezat et al., 2007), we defined easily weathered minerals as those that can be removed by a $1 \mathrm{~mol} \mathrm{~L}^{-1} \mathrm{HNO}_{3}$ solution. Using the chemical composition of the $1 \mathrm{~mol} \mathrm{~L}^{-1} \mathrm{HNO}_{3}$ extract, we inferred the concentration of apatite in the parent materials. We divided soil parent materials into three categories based on their underlying bedrock type. Crystalline silicate rocks included noncarbonate igneous and metamorphic rocks such as gneiss, schist, and granitoid rocks. Clastic sedimentary rocks included shale, siltstone, and sandstone. Carbonate rocks included limestone and dolostone as well as carbonate rocks interlayered with clastic sedimentary rocks.

A comparison of a general geologic map (Fig. 1) and soil distributions in the northeastern United States (NRCS Web Soil Survey, websoilsurvey.nrcs.usda.gov/app/, verified 3 Sept. 2008) shows that bedrock and soil order are roughly correlated in the northeastern United States. That is, Spodosols are common on glacial deposits of crystalline silicate bedrock, Inceptisols are prevalent on the Alleghany Plateau where clastic sedimentary rocks are the major rock type, and Alfisols are located in a narrow belt running east-west across New York where carbonate bedrocks are located. In this study, we limited some of the other variables that affect soil formation (i.e., climate, time for soil development, and topography) by choosing soils in a humid continental climate that have developed on glacial deposits of similar age (left by the last retreat of the Laurentide Ice Sheet) on relatively flat ground.

In addition to studying soil parent materials, we examined the occurrence of easily weathered sources of $\mathrm{Ca}$ and $\mathrm{P}$ in weathered soil horizons. In addition to apatite, some of the P and Ca present in organic matter or adsorbed to $\mathrm{Al}$ and $\mathrm{Fe}$ oxides would be included in this easily weathered fraction (Nezat et al., 2007). We expected to find that apatite was depleted from near-surface soils compared with the soil parent material or $\mathrm{C}$ horizon.

Finally, we tested for a relationship between the amount of easily weathered minerals (apatite and carbonate) in the underlying soil parent materials and the exchangeable Ca concentration of surface soil horizons. Although there are other variables that affect exchangeable $\mathrm{Ca}$ in soil, such as organic matter content and cation exchange capacity, we wanted to examine whether or not exchangeable Ca concentration could be predicted solely from bedrock type.

\section{MATERIALS AND METHODS Site Selection and Sampling}

Thirty-one study sites were selected in New York, Pennsylvania, New Hampshire, and Maine to include a range of igneous, metamorphic, and sedimentary parent materials. In areas covered by ice sheets during the past 20,000 yr, which includes all of our study area, the soil parent materials are glacial deposits, mostly glacial till. Because the till generally represents the bedrock within an $\sim 15$-km radius in the direction from which the glacier advanced (Bailey et al., 2003; Crowl and Sevon, 1999; Isachsen et al., 2000), we selected sites for sampling based on the bedrock composition at and north of each site (Fig. 1, Table 1).

We selected 16 sites underlain by metamorphic and igneous bedrock in Maine, New Hampshire (White Mountains), and New York (Adirondack and Taconic Mountains). The sampling site in Maine, located in the Seaboard Lowland section of the New England Province, is underlain by granite (Osberg et al., 1985). The bedrock at the four sites in the White Mountains is gneiss, granite, and schist (Barton et al., 1997; Lyons et al., 1997). In New York, the Adirondack Mountains are composed primarily of granitoid rocks including charnockite, anorthosite, and mangerite but in the northwest region of the Adirondacks, marble, calcsilicate rock, and quartzite are also present 
(Isachsen et al., 2000). The Taconic Mountains in southeastern New York are composed of schist and quartzite (Isachsen et al., 2000).

Fifteen of the study sites are underlain by sedimentary bedrock and are in the St. Lawrence Valley (northern New York), western New York, and northern Pennsylvania (Fig. 1). In New York, nine sites are underlain by limestone or dolostone, and five sites are underlain by clastic sedimentary rocks, i.e., sandstone, shale, or siltstone (Isachsen et al., 2000). At three sites in the St. Lawrence Valley, proglacial lake deposits lie over carbonate bedrock but are composed of noncarbonate sedimentary deposits; we reclassified these three sites as clastic sedimentary rock.

One soil pit at each of the sampling locations was excavated to the $\mathrm{C}$ horizon. At most of the sites, soil samples were collected from 0 to 10,10 to 20 , and 20 to $30 \mathrm{~cm}$ below the top of the mineral soil, and from the bottom of the soil pit in the $\mathrm{C}$ horizon. The soils collected from Hubbard Brook Experimental Forest were collected by horizon (Nezat et al., 2004).

\section{Bed rock Lithology and Region}

Crystalline-silicate

$\triangle$ Seaboard Lowland

White Mountains

Adirondack Mountains

$\diamond$ Taconic Mountains

Clastic sedimentary

St. Lawrence Valley

Appalachian Plateau

Carbonate

St. Lawrence Valley

Appalachian Plateau

= = Extent of glaciation

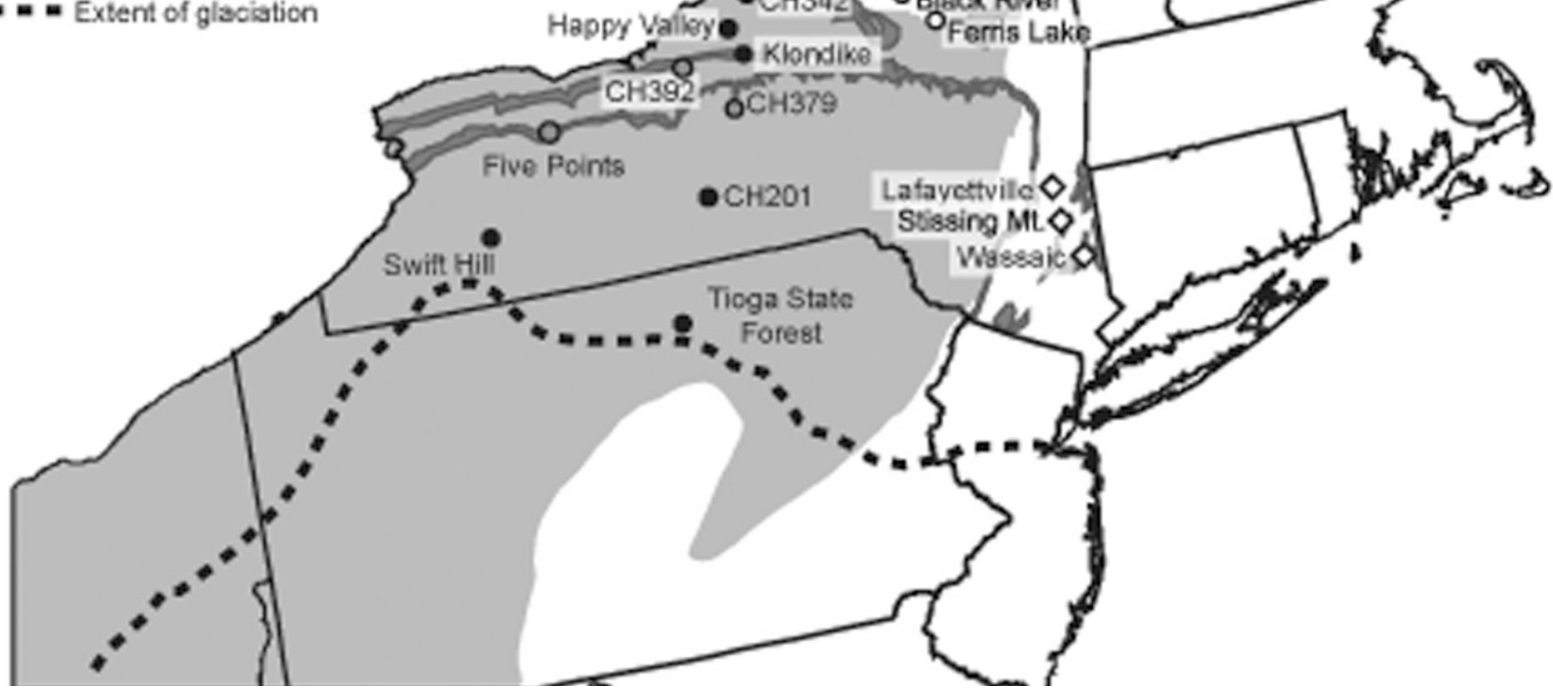

\section{Sample Processing}

All samples were dried at $105^{\circ} \mathrm{C}$ and sieved through a $2-\mathrm{mm}$ screen. Soils were sequentially extracted (Nezat et al., 2007) to identify selected pools of $\mathrm{Ca}, \mathrm{Mg}$, and $\mathrm{P}$. The exchangeable fraction was extracted by mixing $\sim 0.5 \mathrm{~g}$ of soil with $5 \mathrm{~mL}$ of $1 \mathrm{~mol} \mathrm{~L}^{-1} \mathrm{NH}_{4} \mathrm{Cl}$ on a shaker table for $\sim 18 \mathrm{~h}$ at room temperature. To dissolve apatite and carbonates, the residual material was then shaken with $1 \mathrm{~mol} \mathrm{~L}^{-1}$ $\mathrm{HNO}_{3}$ for $18 \mathrm{~h}$ at $10^{\circ} \mathrm{C}$ (Nezat et al., 2007). After each extraction, the mixture was centrifuged and the supernatant was collected and filtered through a $0.45-\mu \mathrm{m}$ membrane. All $1 \mathrm{~mol} \mathrm{~L}^{-1} \mathrm{NH}_{4} \mathrm{Cl}$ and $1 \mathrm{~mol} \mathrm{~L}^{-1} \mathrm{HNO}_{3}$ extracts were evaporated to dryness on a hot plate and redissolved in $5 \% \mathrm{HNO}_{3}$.

Both the exchangeable and $1 \mathrm{~mol} \mathrm{~L}^{-1} \mathrm{HNO}_{3}$ extractable fractions were then diluted with $2 \% \mathrm{HNO}_{3}$ and analyzed for $\mathrm{Ca}, \mathrm{Mg}$, and $\mathrm{P}$ concentrations on a PerkinElmer Optima 3300DV inductively coupled plasma-optical emission spectrometer (PerkinElmer, Norwalk, CT) using a five- to eight-point calibration curve. Analysis of a certified reference material (Soil Solution A, High Purity Standards, Charleston, SC) indicated an accuracy of $\pm 5 \%$.

Fig. 1. Location of samples collected in the northeastern United States. 
To verify the presence of apatite and explore its relationship with other minerals in crystalline silicate soils, we examined six of the soil parent materials collected from the Adirondack Mountains, New York. Samples were sieved to obtain the $250-\mu \mathrm{m}$ to $2-\mathrm{mm}$ size fraction. Subsamples of this fraction were impregnated with epoxy and prepared as polished thin sections. Minerals were identified using an energy dispersive spectrometer on a Hitachi S3200N scanning electron microscope (Hitachi High Technologies, Schaumberg, IL).

\section{Data Analysis}

To test the null hypothesis that soil chemistry did not differ among bedrock types, a two-tailed Student's $t$-test, assuming equal variances, was performed on each pair. Because skewness and kurtosis values indicated that data were not normally distributed, data were log-transformed before statistical analysis in order to satisfy this requirement for the $t$-test. The equality of the variances of the groups was tested using an $F$ test. Significance was tested at $\alpha=0.05$.

\section{RESULTS \\ Identification of Calcium- and Phosphorus- Bearing Minerals in Soil Parent Materials}

We used a $1 \mathrm{~mol} \mathrm{~L}^{-1} \mathrm{HNO}_{3}$ extract of samples from 31 sites to determine which soil parent materials in the northeastern United States contained apatite (Fig. 2). Because this extract dissolves apatite congruently (Nezat et al., 2007), soil parent materials containing apatite as the primary source of easily weathered $\mathrm{Ca}$ and $\mathrm{P}$ should have a $\mathrm{P} / \mathrm{Ca}$ ratio of 3:5, the stoichiometric ratio in apatite.

Most of the soil parent material derived from crystalline silicate rocks had a $\mathrm{P} / \mathrm{Ca}$ ratio in the $1 \mathrm{~mol} \mathrm{~L}^{-1} \mathrm{HNO}_{3}$ extract close to 3:5 (Fig. 2b). Calcium concentrations ranged from 0.2 to $41 \mathrm{mmol} \mathrm{kg}^{-1}$ soil and $\mathrm{P}$ ranged from 1.1 to $27 \mathrm{mmol} \mathrm{kg}^{-1}$ soil, indicating that these soil parent materials varied widely in apatite concentration (0.002-0.4\% apatite in soil by weight based on Ca concentrations). These soil parent materials did not differ systematically by region. For example,

Table 1. Sampling locations in the northeastern United States. The bedrock at each site includes bedrock found up to $10 \mathrm{~km}$ northward. The surficial deposits are glacial till at all sites except for Brasher Falls (northwest), Fort Jackson, and Southville, which have proglacial lake deposits.

\begin{tabular}{|c|c|c|c|c|c|}
\hline Location & State & & Latitude & Longitude & Bedrock \\
\hline \multicolumn{6}{|l|}{ Crystalline silicate bedrock } \\
\hline Osborn & ME & Seaboard Lowland & $44^{\circ} 48^{\prime}$ & $68^{\circ} 16^{\prime}$ & alkali feldspar granite \\
\hline Iron Mountain (T30) & $\mathrm{NH}$ & White Mtns. & $44^{\circ} 9^{\prime}$ & $71^{\circ} 14^{\prime}$ & pelitic schist \\
\hline Bartlett Exp. Forest (H1) & $\mathrm{NH}$ & White Mtns. & $44^{\circ} 3^{\prime}$ & $71^{\circ} 17^{\prime}$ & granite, syenite \\
\hline Sabbaday Falls (M6) & $\mathrm{NH}$ & White Mtns. & $44^{\circ} 0^{\prime}$ & $71^{\circ} 25^{\prime}$ & granite, syenite \\
\hline Hubbard Brook Exp. Forest & $\mathrm{NH}$ & White Mtns. & $43^{\circ} 57^{\prime}$ & $71^{\circ} 43^{\prime}$ & granodiorite, pelitic schist \\
\hline Hopkinton & NY & Adirondack Mtns. & $44^{\circ} 31^{\prime}$ & $74^{\circ} 36^{\prime}$ & charnockite, granitic and quartz syenite gneiss \\
\hline Altamont & NY & Adirondack Mtns. & $44^{\circ} 16^{\prime}$ & $74^{\circ} 27^{\prime}$ & $\begin{array}{l}\text { mangerite, syenite gneiss, charnockite, } \\
\text { metasedimentary rock, granitic gneiss }\end{array}$ \\
\hline Sand Pond & NY & Adirondack Mtns. & $43^{\circ} 57^{\prime}$ & $73^{\circ} 54^{\prime}$ & metanorthosite, anorthositic gneiss \\
\hline Wolf Pond & NY & Adirondack Mtns. & $43^{\circ} 54^{\prime}$ & $74^{\circ} 21^{\prime}$ & charnockite, granitic and quartz syenite gneiss \\
\hline Old Squaw & NY & Adirondack Mtns. & $43^{\circ} 44^{\prime}$ & $74^{\circ} 22^{\prime}$ & $\begin{array}{l}\text { gabbroic metanorthosite, anorthositic gneiss, } \\
\text { mangerite to charnockitic gneiss }\end{array}$ \\
\hline Day & NY & Adirondack Mtns. & $43^{\circ} 20^{\prime}$ & $74^{\circ} 3^{\prime}$ & $\begin{array}{l}\text { biotite and hornblende granitic gneiss, } \\
\text { metasedimentary rock, migmatite }\end{array}$ \\
\hline Black River & NY & Adirondack Mtns. & $43^{\circ} 34^{\prime}$ & $74^{\circ} 51^{\prime}$ & metasedimentary rock, granitic gneiss, marble \\
\hline Ferris Lake & NY & Adirondack Mtns. & $43^{\circ} 24^{\prime}$ & $74^{\circ} 42^{\prime}$ & metasedimentary rock, granitic gneiss \\
\hline Lafayetteville & NY & Taconic Mtns. & $41^{\circ} 58^{\prime}$ & $73^{\circ} 43^{\prime}$ & slate, phyllite, schist, dolostone, sandstone \\
\hline Stissing Mt. & NY & Taconic Mtns. & $41^{\circ} 56^{\prime}$ & $73^{\circ} 41^{\prime}$ & slate, phyllite, schist \\
\hline Wassaic & NY & Taconic Mtns. & $41^{\circ} 47^{\prime}$ & $73^{\circ} 34^{\prime}$ & slate, phyllite, schist, marble \\
\hline \multicolumn{6}{|l|}{ Sedimentary bedrock (clastic) } \\
\hline Brasher Falls (northwest) & NY & St. Lawrence Valley & $44^{\circ} 52^{\prime}$ & $74^{\circ} 50^{\prime}$ & limestone, dolostone \\
\hline Fort Jackson & NY & St. Lawrence Valley & $44^{\circ} 43^{\prime}$ & $74^{\circ} 45^{\prime}$ & dolostone, sandstone, siltstone \\
\hline Southville & NY & St. Lawrence Valley & $44^{\circ} 41^{\prime}$ & $74^{\circ} 51^{\prime}$ & dolostone, sandstone, siltstone \\
\hline $\mathrm{CH} 201$ & NY & Alleghany Plateau & $42^{\circ} 38^{\prime}$ & $76^{\circ} 24^{\prime}$ & shale \\
\hline $\mathrm{CH} 342$ & NY & Alleghany Plateau & $43^{\circ} 30^{\prime}$ & $75^{\circ} 58^{\prime}$ & sandstone, shale \\
\hline Happy Valley & NY & Alleghany Plateau & $43^{\circ} 27^{\prime}$ & $76^{\circ} 2^{\prime}$ & sandstone, siltstone, shale \\
\hline Klondike & NY & Alleghany Plateau & $43^{\circ} 22^{\prime}$ & $75^{\circ} 59^{\prime}$ & sandstone, shale \\
\hline Swift Hill & NY & Alleghany Plateau & $42^{\circ} 27^{\prime}$ & $78^{\circ} 14^{\prime}$ & shale and siltstone \\
\hline Tioga State Forest, Gleason & PA & Alleghany Plateau & $41^{\circ} 39^{\prime}$ & $76^{\circ} 56^{\prime}$ & sandstone \\
\hline \multicolumn{6}{|l|}{ Sedimentary bedrock (carbonate) } \\
\hline Brasher Falls (southeast) & NY & St. Lawrence Valley & $44^{\circ} 51^{\prime}$ & $74^{\circ} 39^{\prime}$ & limestone, dolostone \\
\hline Grantville & NY & St. Lawrence Valley & $44^{\circ} 51^{\prime}$ & $74^{\circ} 55^{\prime}$ & limestone, dolostone \\
\hline Black Pond & NY & Alleghany Plateau & $43^{\circ} 47^{\prime}$ & $76^{\circ} 12^{\prime}$ & limestone, shale \\
\hline $\mathrm{CH} 392$ & NY & Alleghany Plateau & $43^{\circ} 11^{\prime}$ & $76^{\circ} 41^{\prime}$ & limestone, dolostone \\
\hline $\mathrm{CH} 379$ & NY & Alleghany Plateau & $43^{\circ} 1^{\prime}$ & $76^{\circ} 22^{\prime}$ & limestone, dolostone \\
\hline Rush & NY & Alleghany Plateau & $42^{\circ} 58^{\prime}$ & $77^{\circ} 40^{\prime}$ & limestone, dolostone \\
\hline
\end{tabular}



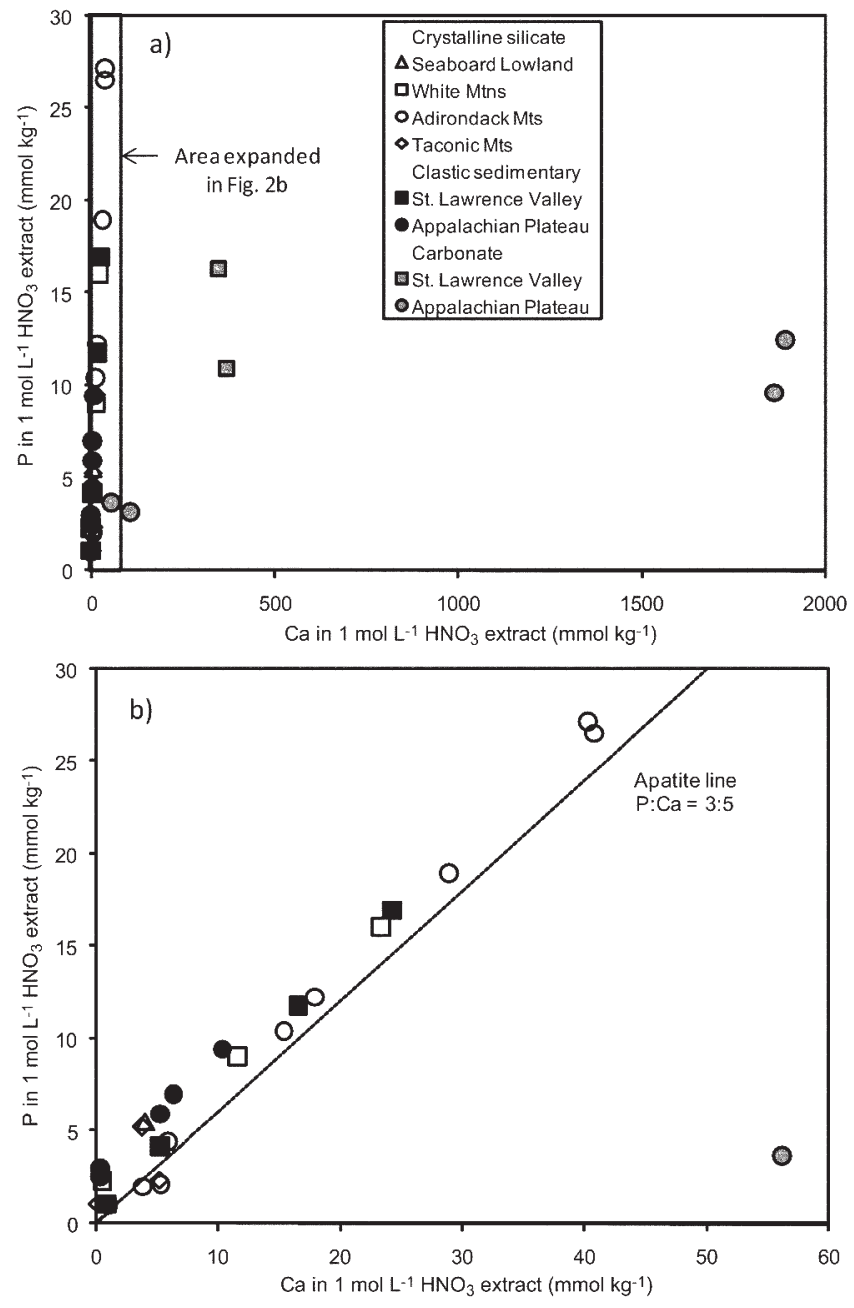

Fig. 2. Phosphorus vs. Ca from a $1 \mathrm{~mol} \mathrm{~L}^{-1} \mathrm{HNO}_{3}$ extraction (at 10 ${ }^{\circ} \mathrm{C}$ ) of $\mathrm{C}$ horizon samples from across the northeastern United States: (a) all data—not surprisingly, carbonate-rich sites have the highest Ca concentrations; (b) an enlarged view at low Ca concentrations. Many of the parent materials derived from crystalline silicate and clastic sedimentary rocks fall near the dashed line, which represents the $\mathrm{P} / \mathrm{Ca}$ ratio of apatite (3:5).

the Adirondacks had sites with the highest and some of the lowest apatite concentrations. Some of the soils derived from crystalline silicate rocks (Osborn, Stissing Mountain, Sabbaday
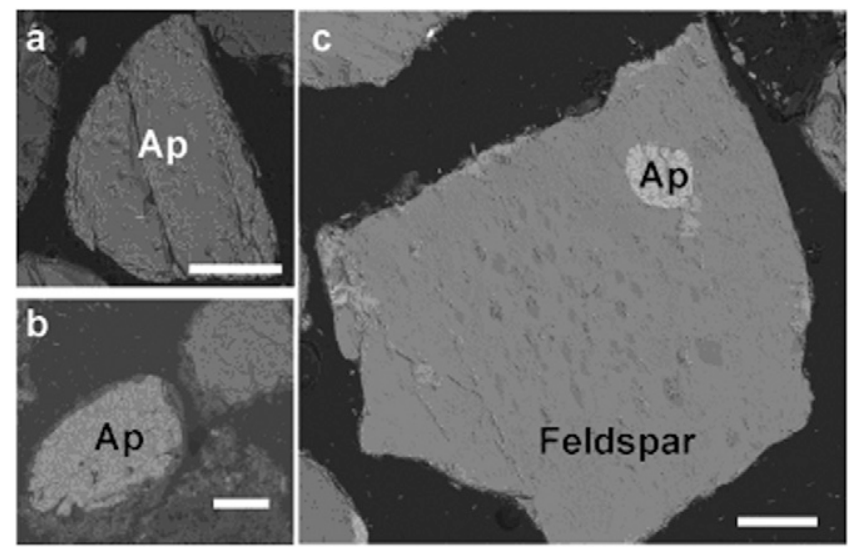

Fig. 3. Scanning electron microscopy (SEM) images of apatite (Ap) in Adirondack soils collected from (a) Old Squaw, (b) Day, and (c) Sand Pond. The scale bar is $\mathbf{1 0 0} \mu \mathrm{m}$ long.
Falls, and Lafayettville) had $\mathrm{P} / \mathrm{Ca}>3: 5$, suggesting the presence of other $\mathrm{P}$ sources in addition to apatite.

Soils collected from clastic sedimentary sites (located on the Appalachian Plateau) generally had $\mathrm{Ca}$ and $\mathrm{P}$ concentrations that were not significantly different from the crystalline-silicate soils $(P$ $=0.22$ for $\mathrm{Ca}$ and 0.80 for $\mathrm{P}$ ); however, the $\mathrm{P} / \mathrm{Ca}$ ratio was typically $>3: 5$ (Fig. 2b), suggesting other sources of $P$ besides apatite.

Three sites in the St. Lawrence Valley (Brasher Falls northwest, Fort Jackson, and Southville) overlie carbonate bedrock, but are in an area where carbonate-poor glacial lake deposits blanket glacial till. The lack of abundant $\mathrm{Ca}$ in the $1 \mathrm{~mol} \mathrm{~L}^{-1} \mathrm{HNO}_{3}$ extract and the $\mathrm{P} / \mathrm{Ca}$ ratio of $3: 5$ is consistent with the origin of these three soil parent materials as siliclastic glacial lake deposits rather than carbonate-rich glacial till. Field textural analysis confirmed that these soil parent materials were composed of well-sorted sand, which also indicates that they are lakeshore deposits and not glacial till.

Soil parent materials underlain by carbonate bedrock had significantly higher $\mathrm{Ca}$ concentrations in the $1 \mathrm{~mol} \mathrm{~L}^{-1}$ $\mathrm{HNO}_{3}$ extract than soils derived from crystalline silicate and clastic sedimentary rocks $(P<0.001$; Fig. $2 \mathrm{a})$. These sites also had high concentrations of $1 \mathrm{~mol} \mathrm{~L}^{-1} \mathrm{HNO}_{3}$ extractable $\mathrm{Mg}\left(252-344 \mathrm{mmol} \mathrm{Mg} \mathrm{kg}^{-1}\right.$ soil) relative to other sites ( $<75 \mathrm{mmol} \mathrm{Mg} \mathrm{kg}{ }^{-1}$ soil), suggesting the presence of dolomite or high-Mg calcite. Phosphorus was present in these materials at concentrations that did not differ significantly from those at the noncarbonate sites $(P>0.33)$.

To investigate the relationship between apatite and silicate minerals in granitoid parent materials, we examined thin sections of soil parent materials from the Adirondack Mountains. We found apatite either as individual grains (Fig. 3a), partially included in silicate minerals (Fig. 3b), or completely included in silicate minerals (Fig. 3c). Apatite grains ranged from 50 to $300 \mu \mathrm{m}$ in diameter.

We examined bedrock type as an explanation of the regional pattern in available ( $1 \mathrm{~mol} \mathrm{~L}-1 \mathrm{HNO}_{3}$ extractable) Ca in soil parent material (Fig. 4). It is clear from the map that the highest $\mathrm{Ca}$ availability is located near carbonate bedrock. As described above, however, three of the five sites in the St. Lawrence Valley overlying carbonate bedrock did not contain any evidence of carbonates.

\section{Easily Extracted Calcium and Phosphorus in Upper Soil Profiles}

We determined the $1 \mathrm{~mol} \mathrm{~L}^{-1} \mathrm{HNO}_{3}$ extractable $\mathrm{Ca}$ and $\mathrm{P}$ in the upper soil profile (Fig. 5). Not surprisingly, carbonatedominated soils generally had higher $\mathrm{Ca}$ concentrations than the soils overlying crystalline silicate or clastic sedimentary bedrock. Generally, the $\mathrm{Ca}$ and $\mathrm{P}$ concentrations were lower in the surface soils than the parent materials (Fig. 2), as expected due to apatite weathering, plant uptake, and leaching. Notable exceptions were Lafayetteville, a crystalline silicate bedrock site in which the $\mathrm{Ca}$ in the 0 - to $10-\mathrm{cm}$ sample was three times that in the $\mathrm{C}$ horizon, and Swift Hill (clastic sedimentary) and Black Pond (carbonate), in which the P was 16 and five times, respectively, in surface horizons what it was in the $\mathrm{C}$ horizon. These sites are probably cases where the $\mathrm{C}$ horizon is not representative of the parent material for the upper portion of the profile. Three additional sites had more modest excesses (up to threefold) of $\mathrm{P}$ concentrations in this extract in the surface 
soils compared with the C horizon: H1, CH 201, and Stissing Mountain. Excluding these six sites, the concentration of $\mathrm{Ca}$ in the surface soils (averaging up to three layers per site) as a fraction of the concentration in the $\mathrm{C}$ horizon was 28\% (13 crystalline silicate sites), 22\% (four clastic sedimentary sites), and $14 \%$ (eight carbonate sites). For P, these fractions were $35 \%$ (crystalline silicates), 25\% (clastic sedimentary sites), and $41 \%$ (carbonates). The difference between the retention of $\mathrm{Ca}$ and $\mathrm{P}$ was not significant $(P>0.4$ in paired $t$-tests $)$ except in the case of the carbonate sites $(P=0.03)$.

\section{Relationship between Exchangeable Calcium in Upper Soils and Soil Parent Material}

We tested the dependence of soil Ca availability on the type of parent material by comparing the exchangeable Ca concentration at the 10 - to $20-\mathrm{cm}$ depth to the $\mathrm{Ca}$ in the $1 \mathrm{~mol} \mathrm{~L}-1$ $\mathrm{HNO}_{3}$ extract of the respective soil parent material (Fig. 6). Not surprisingly, soils formed on carbonate-dominated soils had the highest exchangeable Ca concentrations, whereas soils formed on clastic sedimentary and crystalline silicate rocks had approximately an order of magnitude less exchangeable $\mathrm{Ca}$. The exchangeable $\mathrm{Ca}$ at 10 to $20 \mathrm{~cm}$ was correlated with the easily extracted $\mathrm{Ca}$ in the $1 \mathrm{~mol} \mathrm{~L}^{-1} \mathrm{HNO}_{3}$ extract of the soil parent material $\left(P<0.001, r^{2}=0.52\right)$. This pattern, however, was driven by the high $\mathrm{Ca}$ concentrations in the carbonate soils. When the carbonate sites were omitted from the analysis, there was no significant relationship $\left(P=0.56, r^{2}=0.01\right)$.

\section{DISCUSSION}

\section{Apatite in soil parent materials}

The importance of apatite in young soils at the Hubbard Brook Experimental Forest in New Hampshire has previously been reported (Blum et al., 2002; Nezat et al., 2004; Yanai et al., 2005). Because apatite is common in crystalline silicate rocks, we predicted that soil parent materials in other young soils in the northeastern United States that were derived from crystalline silicate rocks would also contain apatite. We identified apatite in most of these soil parent materials based on the similarity between the $\mathrm{P} / \mathrm{Ca}$ ratio in the $1 \mathrm{~mol} \mathrm{~L}^{-1} \mathrm{HNO}_{3}$ extract and that in apatite (3:5) (Fig. 2b). Some of the soils derived from crystalline silicate rocks (Osborn, Stissing

\section{Bedrock Lithology \\ $\bigcirc$ Crystalline-silicate \\ Clastic sedimentary \\ Carbonate \\ Extent of glaciation}

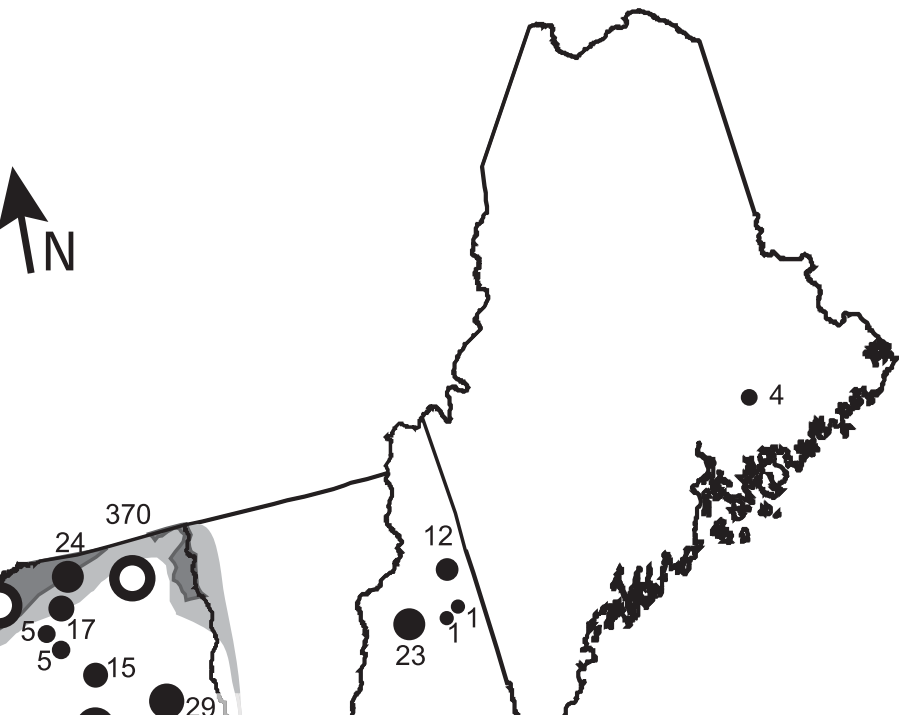

Ca concentration ( $\mathrm{mmol} \mathrm{kg}^{-1}$ soil) in $1 \mathrm{~mol} \mathrm{~L}^{-1} \mathrm{HNO}_{3}$ extract of soil parent material

$<100$ (size of circle proportional to concentration)

(-) $100-1000$

(.) $>1000$

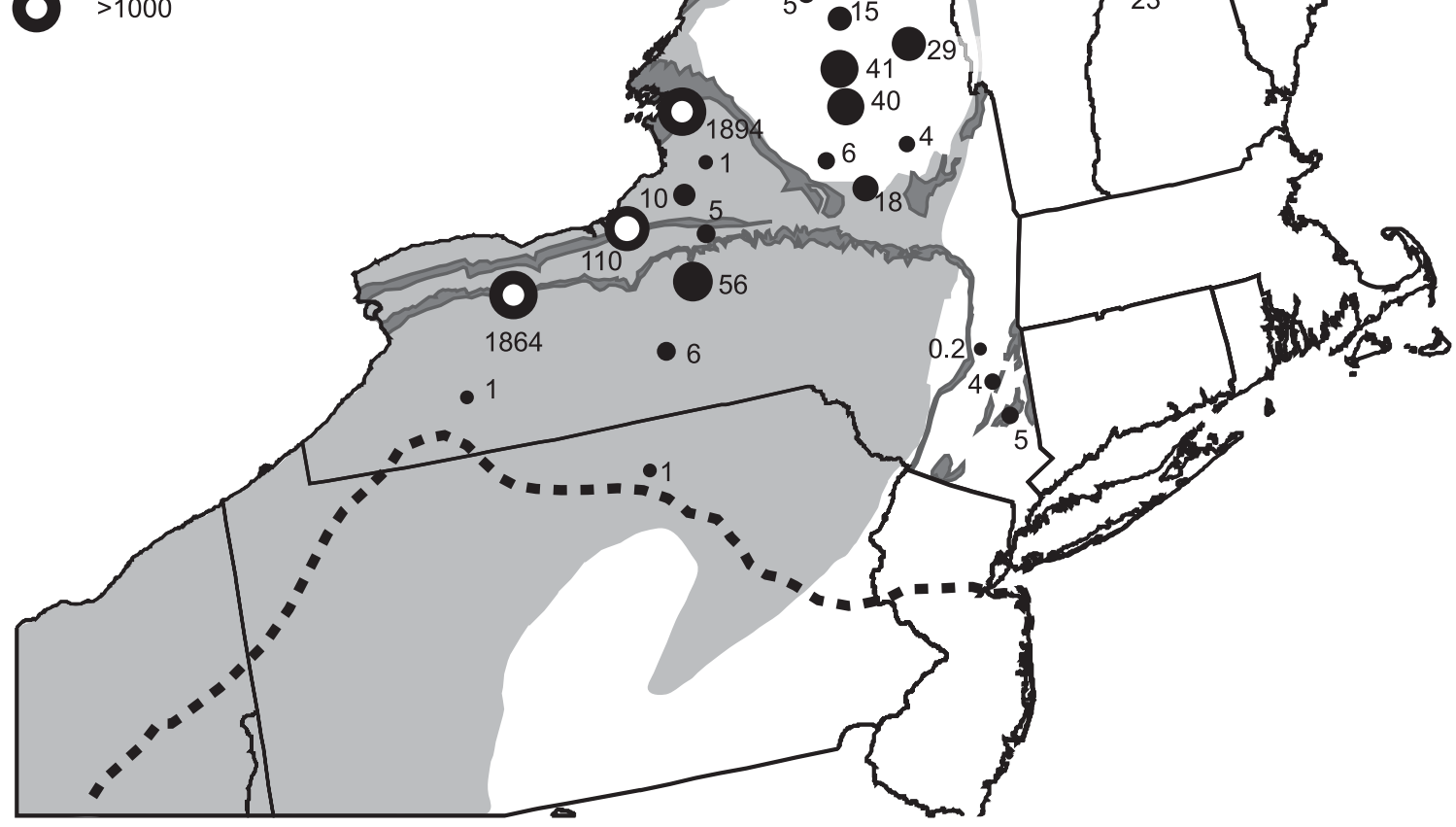

Fig. 4. Calcium concentration in $1 \mathrm{~mol} \mathrm{~L}^{-1} \mathrm{HNO}_{3}$ extract of soil parent materials. 


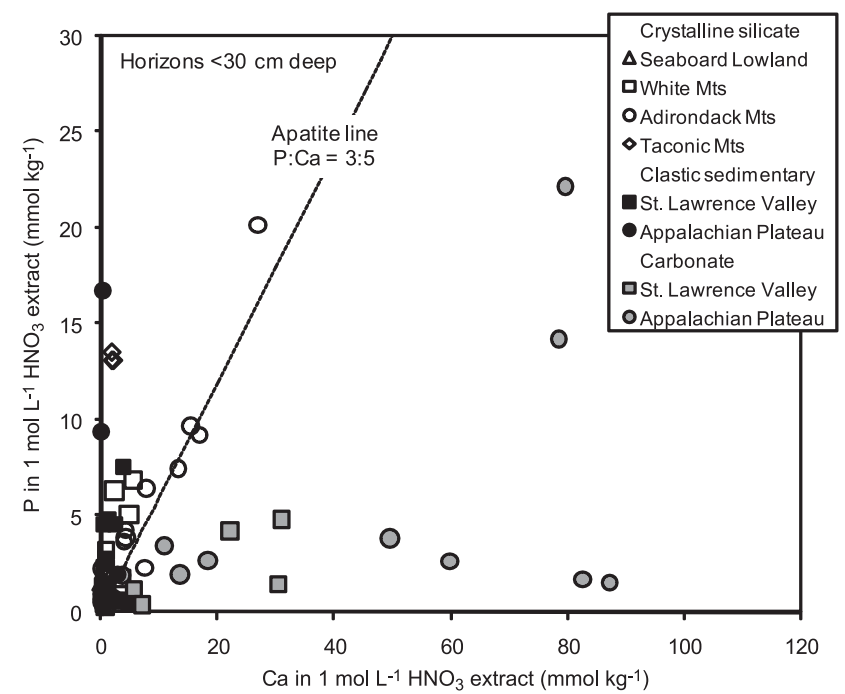

Fig. 5. Phosphorus vs. Ca from a $1 \mathrm{~mol} \mathrm{~L}^{-1} \mathrm{HNO}_{3}$ extraction (at 10 ${ }^{\circ} \mathrm{C}$ ) of surface soils (<30 cm deep) from across the northeastern United States. Each site is represented by two to three samples collected roughly at 5,15 , and $25 \mathrm{~cm}$.

Mountain, Sabbaday Falls, and Lafayettville) had P/Ca ratios $>3: 5$, suggesting the presence of other $\mathrm{P}$ sources in addition to apatite. In fact, the $1 \mathrm{~mol} \mathrm{~L}^{-1} \mathrm{HNO}_{3}$ solution also extracts $\mathrm{Ca}$ and $\mathrm{P}$ from organic matter and weathering products such as $\mathrm{P}$ adsorbed to $\mathrm{Al}$ and Fe oxides (Nezat et al., 2007), which are typically a negligible fraction of soil parent materials derived from crystalline silicate rocks. Monazite, another primary phosphate mineral found in crystalline silicate rocks, is less common than apatite and is not likely to be extracted by a $1 \mathrm{~mol} \mathrm{~L}^{-1} \mathrm{HNO}_{3}$ solution (Nezat et al., 2007).

In addition to its presence in igneous and metamorphic rocks, apatite is also found in a variety of sedimentary rocks as detrital, authigenic, or biological apatite (Bouch et al., 2002; Knudsen and Gunter, 2002; Rasmussen, 1996). Although Ca and $\mathrm{P}$ were present in the $1 \mathrm{~mol} \mathrm{~L}^{-1} \mathrm{HNO}_{3}$ extract of most of the soil parent materials derived from the sedimentary rocks, the $\mathrm{P} / \mathrm{Ca}$ ratio for most of these samples was $>3: 5$, indicating other sources of $\mathrm{P}$ in addition to apatite. In the region we studied, young soils developed from crystalline silicate and clastic

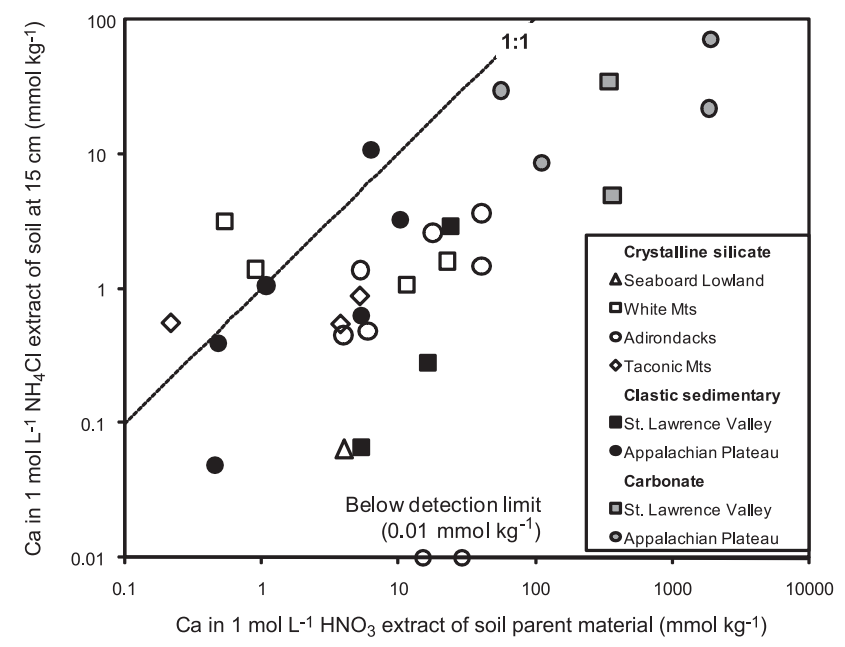

Fig. 6. Calcium concentration of a $1 \mathrm{~mol} \mathrm{~L}^{-1} \mathrm{NH}_{4} \mathrm{Cl}$ extract of soil at 10 to $20-\mathrm{cm}$ depth vs. Ca concentration of a $1 \mathrm{~mol} \mathrm{~L}^{-1} \mathrm{HNO}_{3}$ extract of soil parent material. The dashed line represents a 1:1 ratio. (noncarbonate) sedimentary rocks have similar ranges of easily weathered $\mathrm{Ca}$ and P (Fig. 2b).

Carbonate rocks also contain apatite, often as carbonate-apatite (Knudsen and Gunter, 2002). Because the $1 \mathrm{~mol} \mathrm{~L}^{-1} \mathrm{HNO}_{3}$ extract also dissolves calcite, we used the $\mathrm{P}$ concentration to estimate the concentration of apatite in these soil parent materials. Although carbonate-rich soil parent materials contain considerably more $1 \mathrm{~mol} \mathrm{~L}^{-1} \mathrm{HNO}_{3}$ extractable $\mathrm{Ca}$, the concentration of easily weathered $\mathrm{P}$ in carbonate parent materials is similar to that found in crystalline silicate and clastic sedimentary parent materials (Fig. 2a).

The concentration of apatite estimated from the $\mathrm{Ca}$ and $P$ concentrations in the $1 \mathrm{~mol} \mathrm{~L}^{-1} \mathrm{HNO}_{3}$ extract may be less than the total because some apatite may occur as inclusions in, and may be completely armored by, weathering-resistant minerals such as biotite, plagioclase, and $\mathrm{K}$ feldspar, which are not dissolved by this extract (Nezat et al., 2007). Unlike apatite inclusions, apatite that is present as free grains or partially included in silicate minerals may be exposed to the soil solution and release nutrients during weathering. At the Hubbard Brook Experiment Forest, $70 \%$ of the total $\mathrm{P}$ in the soil parent materials was removed by the $1 \mathrm{~mol} \mathrm{~L}^{-1} \mathrm{HNO}_{3}$ extract (Nezat et al., 2004), indicating that the remaining $30 \%$ was from apatite inclusions and other P-bearing minerals such as monazite. In the current study, a range of 10 to $100 \%$ of the total $P$ was removed by the $1 \mathrm{~mol} \mathrm{~L}^{-1} \mathrm{HNO}_{3}$ extract from the soil parent materials (data not shown) with no pattern among bedrock type or geographic region. While this extraction method quantifies the amount of apatite that is currently exposed to soil solution, biological, chemical, and physical processes are continually occurring in soils and may expose more apatite with time. For example, this method does not account for apatite inclusions that may be accessed by mycorrhizal fungi as they tunnel through silicate minerals (Jongmans et al., 1997; Landeweert et al., 2001). To determine total apatite using this extraction method, soils should be pulverized before extraction. In this study, we extracted untreated soils because we were interested in apatite currently susceptible to weathering.

\section{Easily Weathered Minerals in the Upper Soil Profile}

Although apatite is present in soil parent materials, it can be weathered from surface soils in a few thousand years due to its rapid weathering rate (Crews et al., 1995). Assuming that the original composition of surface soils was similar to the soil parent material and that inputs from atmospheric dust have been minor, apatite concentrations in the soil should increase with depth due to the decrease in weathering (Schlesinger et al., 1998). At the Hubbard Brook Experimental Forest, apatite was identified in lower B horizons (Blum et al., 2002), suggesting that apatite has not been completely weathered at this depth.

As apatite weathers, $\mathrm{P}$ accumulates in organic matter or binds to $\mathrm{Al}$ and $\mathrm{Fe}$ oxides (Crews et al., 1995; Schlesinger et al., 1998; Walker and Syers, 1976). The $1 \mathrm{~mol} \mathrm{~L}^{-1} \mathrm{HNO}_{3}$ solution releases $\mathrm{Ca}$ and $\mathrm{P}$ from both of these pools as well as from apatite (Nezat et al., 2007), making it difficult to estimate the concentration of apatite present in these soil horizons. The portion of $\mathrm{P}$ concentration loss we report (two-thirds in crystalline silicates and three-quarters in clastic sedimentary sites) should be a conservative estimate of the portion of apatite weathered, both because of the weathering products appearing in this 
operationally defined pool and also because of the loss of other elements from the profile. The concentration of an immobile element as an indicator of mass loss, combined with identification of apatite crystals, could give a more exact measure of apatite loss. It has been suggested that $\mathrm{P}$ may be more tightly retained than $\mathrm{Ca}$ in surface horizons due to high ecosystem demand relative to its lithologic supply (Jobbágy and Jackson, 2001); however, we did not find a greater fraction of $\mathrm{Ca}$ than $\mathrm{P}$ lost from the upper part of the profile, relative to the $\mathrm{C}$ horizon, except in the carbonate sites.

\section{Effect of Soil Parent Material on the Exchangeable Fraction}

The relationship we found between easily weathered $\mathrm{Ca}$ in parent materials and exchangeable $\mathrm{Ca}$ in soils is informative because it may give a first-order approach to identifying soils that have high exchangeable $\mathrm{Ca}$ concentrations. Where the composition of the bedrock is well known, it would be very appealing to use a bedrock map to predict the area most susceptible to $\mathrm{Ca}$ depletion and soil acidification. There are some limitations to this approach, however. First, the surficial geology also needs to be considered. Although glacial till is typically derived from local bedrock, other glacial deposits are not. For example, glacial lake deposits located in the St. Lawrence Valley (at Brasher Falls northwest, Southville, and Fort Jackson) are carbonate poor despite the fact that they are underlain by calcareous bedrock. In nearby soils that are underlain by the same bedrock but developed on glacial till (e.g., Brasher Falls southeast and Grantville), carbonates are present. Second, it is important to keep in mind that there is a wide variation in parent material composition within the broad categories of crystalline silicate and clastic sedimentary rocks, which influences soil mineral and chemical composition (Fig. 2). To predict the availability of $\mathrm{Ca}$ and $\mathrm{P}$ to vegetation and the susceptibility of soils to acidification at specific sites would require detailed characterization of the glacial till composition (Bailey and Hornbeck, 1992; Hornbeck et al., 1997), along with an evaluation of the soil's capacity to retain exchangeable Ca.

\section{CONCLUSIONS}

Using a new sequential extraction method, we quantified the concentration of "easily weathered" $\mathrm{Ca}$ and $\mathrm{P}$ pools, such as apatite and carbonate, in soil parent materials derived from a variety of bedrock types. The similarity between the $\mathrm{P} / \mathrm{Ca}$ ratio in apatite and the $1 \mathrm{~mol} \mathrm{~L}^{-1} \mathrm{HNO}_{3}$ extract indicates that apatite is the dominant source of $\mathrm{P}$ and $\mathrm{Ca}$ in this easily weathered pool in most soil parent materials derived from crystalline silicate rocks. This method also distinguishes the apatite that is exposed to soil solution from that which is completely armored by weathering-resistant silicate minerals and thus not currently susceptible to weathering.

Although known as the dominant P-bearing primary mineral in soil, apatite has not been studied as a source of $\mathrm{Ca}$ in soils until recently. In this study, we have shown that apatite is present in many parent materials of young soils in the northeastern United States where Ca depletion is a concern. Previous methods of characterizing soil $\mathrm{Ca}$ and $\mathrm{P}$ do not routinely identify the apatite fraction. Although usually present in trace amounts, apatite dissolves orders of magnitude more rapidly than plagioclase, the dominant $\mathrm{Ca}$-bearing silicate mineral in many soils. To predict changes in plant-available
Ca concentrations in soil in response to acid deposition and forest harvesting, it is important to be able to quantify this Ca pool.

\section{ACKNOWLEDGMENTS}

We wish to thank our industry collaborators who provided site locations: Robert O'Brien, Cotton-Hanlon, Inc.; Roger Dziengaleski and Dave Osterberg, Finch Pruyn \& Company; Tom Hall, Pennsylvania Department of Conservation and Natural Resources; and Phil Malerba and Cathy Irwin, International Paper. Samples were collected by Amber Knowlden, Byung Bae Park, Megan Rose Newhouse, Ryan Maher, Jackie Borza, Adrienne Graham, and Amy Smith. Financial support was provided by the New York State Energy Research and Development Authority, the Agenda 2020 collaboration between forest industry and the U.S. Forest Service, and the National Science Foundation (DEB 0235650 and 0423259). This paper is a contribution to the Hubbard Brook Ecosystem Study, which is maintained by the U.S. Forest Service and participates in the NSF Long-Term Ecological Research program.

\section{REFERENCES}

Bailey, S.W., D.C. Buso, and G.E. Likens. 2003. Implications of sodium mass balance for interpreting the calcium cycle of a northern hardwood ecosystem. Ecology 84:471-484.

Bailey, S.W., and J.W. Hornbeck. 1992. Lithologic composition and rock weathering potential of forested, glacial-till soils. Res. Pap. NE-662. U.S For. Serv., Northeastern For. Exp. Stn., Radnor, PA.

Barton, C.C., R.H. Camerlo, and S.W. Bailey. 1997. Bedrock geologic map of Hubbard Brook Experimental Forest. Misc. Invest. Ser. Map I-2562. USGS, Reston, VA.

Beck, M.A., and H. Elsenbeer. 1999. Biogeochemical cycles of soil phosphorous in southern alpine Spodosols. Geoderma 91:249-260.

Blum, J.D., A. Klaue, C.A. Nezat, C.T. Driscoll, C.E. Johnson, T.G. Siccama, C. Eagar, T.J. Fahey, and G.E. Likens. 2002. Mycorrhizal weathering of apatite as an important calcium source in base-poor forest ecosystems. Nature 417:729-731.

Bouch, J.E., M.J. Hole, N.H. Trewin, S. Chenery, and A.C. Morton. 2002. Authigenic apatite in a fluvial sandstone sequence: Evidence for rare-earth element mobility during diagenesis and a tool for diagenetic correlation. J. Sediment. Res. 72:59-67.

Crews, T.E., K. Kitayama, J.H. Fownes, R.H. Riley, D.A. Herbert, D. MuellerDombois, and P.M. Vitousek. 1995. Changes in soil phosphorous fractions and ecosystem dynamics across a long chronosequence in Hawaii. Ecology 76:1407-1424.

Crowl, G.H., and W.D. Sevon. 1999. Quaternary. p. 225-231. In C.H. Shultz (ed.) Geology of Pennsylvania. Penn. Geol. Surv., Harrisburg.

Filippelli, G.M., and C. Souch. 1999. Effects of climate and landscape development on the terrestrial phosphorous cycle. Geology 27:171-174.

Hedley, M.J., J.W.B. Stewart, and B.S. Chauhan. 1982. Changes in inorganic and organic soil phosphorus fractions induced by cultivation practices and by laboratory incubations. Soil Sci. Soc. Am. J. 46:970-976.

Hendershot, W.H., H. Lalande, and M. Duquette. 1993. Ion exchange and exchangeable cations. p. 167-176. In M.R. Carter (ed.) Soil sampling and methods of analysis. Lewis Publ., Boca Raton, FL.

Hornbeck, J.W., S.W. Bailey, D.C. Buso, and J.B. Shanley. 1997. Streamwater chemistry and nutrient budgets for forested watersheds in New England: Variability and management implications. For. Ecol. Manage. 93:73-89.

Horsley, S.B., R.P. Long, S.W. Bailey, R.A. Hallet, and T.J. Hall. 2000. Factors associated with the decline disease of sugar maple on the Allegheny Plateau. Can. J. For. Res. 30:1365-1378.

Huntington, T.G. 2005. Assessment of calcium status in Maine forests: Review and future projection. Can. J. For. Res. 35:1109-1121.

Isachsen, Y.W., E. Landing, J.M. Lauber, L.V. Rickard, and W.B. Rogers (ed.). 2000. Geology of New York: A simplified account. N.Y. State Museum, Albany.

Jobbágy, E.G., and R.B. Jackson. 2001. The distribution of soil nutrients with depth: Global patterns and the imprint of plants. Biogeochemistry 53:51-77.

Jongmans, A.G., N. van Breemen, U. Lundstrom, P.A.W. van Hees, R.D. Finlay, M. Srinivasan, T. Unestam, R. Geisler, P.-A. Melkerud, and M. Olsson. 1997. Rock-eating fungi. Nature 389:682-683.

Knudsen, A.C., and M.E. Gunter. 2002. Sedimentary phosphorites-an 
example: Phosphoria Formation, southeastern Idaho, USA. Rev. Mineral. Geochem. 48:363-389.

Kohn, M.J., and T.E. Cerling. 2002. Stable isotope compositions of biological apatite. Rev. Mineral. Geochem. 48:455-488.

Landeweert, R., E. Hoffland, R.D. Finlay, T.W. Kuyper, and N. van Breemen. 2001. Linking plants to rocks: Ecotmycorrhizal fungi mobilize nutrients from minerals. Trends Ecol. Evol. 16:248-253.

Lawrence, G.B., M.B. David, G.M. Lovett, P.S. Murdoch, D.A. Burns, J.L. Stoddard, B.P. Baldigo, J.H. Porter, and A.W. Thompson. 1999. Soil calcium status and the response of stream chemistry to changing acidic deposition rates. Ecol. Appl. 9:1059-1072.

Lichter, J. 1998. Rates of weathering and chemical depletion in soils across a chronosequence of Lake Michigan sand dunes. Geoderma 85:225-282.

Likens, G.E., C.T. Driscoll, D.C. Buso, T.G. Siccama, C.E. Johnson, G.M. Lovett, T.J.Fahey, W.A. Reiners, D.F. Ryan, C.W.Martin, and S.W. Bailey. 1998. The biogeochemistry of calcium at Hubbard Brook. Biogeochemistry 41:89-173.

Long, R.P., S.B. Horsley, and P.R. Lilja. 1997. Impact of forest liming on growth and crown vigor of sugar maple and associated hardwoods. Can. J. For. Res. 27:1560-1573.

Lyons, J.B., W.A. Bothner, R.H. Moench, and J.B. Thompson, Jr. 1997. Bedrock geologic map of New Hampshire. USGS, Reston, VA.

Nezat, C.A., J.D. Blum, A. Klaue, and C.E. Johnson. 2004. Influence of landscape position and vegetation on long-term weathering rates at the Hubbard Brook Experimental Forest, New Hampshire, USA. Geochim. Cosmochim. Acta 68:3065-3078.

Nezat, C.A., J.D. Blum, R.D. Yanai, and S.P. Hamburg. 2007. A sequential extraction to selectively dissolve apatite for determination of soil nutrient pools with an application to Hubbard Brook Experimental Forest, New Hampshire, USA. Appl. Geochem. 22:2406-2421.

Osberg, P.H., A.M. Hussey, and G.M. Boone. 1985. Bedrock geologic map of Maine. Maine Geol. Surv., Augusta.

Oxburgh, R., J.I. Drever, and Y.T. Sun. 1994. Mechanism of plagioclase dissolution in acid solution at $25^{\circ} \mathrm{C}$. Geochim. Cosmochim. Acta 58:661-669.
Piccoli, P.M., and P.A. Candela. 2002. Apatite in igneous systems. Rev. Mineral. Geochem. 48:255-292.

Rasmussen, B. 1996. Early-diagenetic REE-phosphate minerals (florencite, gorceixite, crandallite, and xenotime) in marine sandstones: A major sink for oceanic phosphorus. Am. J. Sci. 296:601-632.

Robertson, G.P., P. Sollins, B.G. Ellis, and K. Lajtha. 1999. Exchangeable ions, $\mathrm{pH}$, and cation exchange capacity. p. 106-114. In G.P. Robertson et al. (ed.) Standard soil methods for long-term ecological research. Vol. 2. Oxford Univ. Press, New York.

Roden-Tice, M.K., and S.J. Tice. 2005. Regional-scale mid-Jurassic to Late Cretaceous unroofing from the Adirondack Mountains through central New England based on apatite fission-track and (U-Th)/He thermochronology. J. Geol. 113:535-552.

Schlesinger, W.H., L.A. Bruijnzeel, M.B. Bush, E.M. Klein, K.A. Mace, J.A. Raikes, and R.J. Whittaker. 1998. The biogeochemistry of phosphorous after the first century of soil development on Rakata Island, Krakatau, Indonesia. Biogeochemistry 40:37-55.

Spear, F.S., and J.M. Pyle. 2002. Apatite, monazite, and xenotime in metamorphic rocks. Rev. Mineral. Geochem. 48:293-335.

Valsami-Jones, E., K.V. Ragnarsdottir, A. Putnis, D. Bosbach, A.J. Kemp, and G. Cressey. 1998. The dissolution of apatite in the presence of aqueous metal cations at $\mathrm{pH}$ 2-7. Chem. Geol. 151:215-233.

Vandenbygaart, A.J., and R. Protz. 1995. Soil genesis on a chronosequence, Pinery Provincial Park, Ontario. Can. J. Soil Sci. 75:63-72.

Walker, T.W., and J.K. Syers. 1976. The fate of phosphorus during pedogenesis. Geoderma 15:1-19.

Welch, S.A., and W.J. Ullman. 1993. The effect of organic acids on plagioclase dissolution rates and stoichiometry. Geochim. Cosmochim. Acta 57:2725-2736.

Yanai, R.D., J.D. Blum, S.P. Hamburg, M.A. Arthur, C.A. Nezat, and T.G. Siccama. 2005. New insights into calcium depletion in northeastern forests. J. For. 103:14-20. 